\title{
Pengaruh Kemampuan Keuangan dan Posisi Fiskal Terhadap Pertumbuhan Ekonomi Kabupaten/Kota Di Provinsi Kalimantan Barat
}

\author{
Anggatia Ariza* \\ IAIN Pontianak
}

\begin{abstract}
The implementation of local autonomy and decentralization empowers the local government to manage their own area largely and properly. The research aims to examine the financial and fiscal position and their effects towards the economic growth of the regencies or cities in West Kalimantan. Moreover, the ${ }^{1}$ financial capability is proxied by the proportion of PDS while the fiscal position is determined by the direct expenditure per capita to verify their effects to the economic growth. This research, furthermore, utilizes the panel data from 12 regencies/cities throughout West Kalimantan in 2006-2010 and used Fixed Effects Method. As a result, the proportion of PDS affects negatively and significantly the economic growth, while the direct expenditure per capita has slightly a negative effect towards the economic growth of regencies/cities in West Kalimantan.
\end{abstract}

Key words: Local Financial Capacity, The Fiscal Position, Proportion of PDS, Direct Expenditures Per Capita, GDP Growth.

\section{PENDAHULUAN}

Pemerintah pusat memberikan otonomi kepada pemerintah daerah agar dapat menyelenggarakan pemerintahannya sendiri. Tujuannya adalah untuk menciptakan kemandirian pemerintah daerah serta meningkatkan efisiensi dan efektivitas sehingga pembangunan di daerah mampu mendorong pertumbuhan ekonomi lokal maupun nasional. Undang-Undang No. 33 tahun 2004 yang mengatur Perimbangan Keuangan antara Pemerintah Pusat dan Pemerintahan daerah menjelaskan bahwa penyelenggaraan urusan pemerintahan diikuti dengan pemberian sumber-sumber penerimaan yang cukup kepada daerah yang disesuaikan dan diselaraskan dengan pembagian kewenangan antara Pemerintah dan Daerah. Sehingga daerah mempunyai hak untuk mengatur dan mengelola sumber-sumber penerimaannya sesuai dengan kepentingan dan kebutuhannya.

* Korespondensi: Anggatia Ariza, Fakultas Syariah dan Ekonomi Islam IAIN Pontianak. Alamat Email : anggatia_ariza@yahoo.co.id . 
Kemampuan pemerintah daerah dalam mengelola keuangan dituangkan dalam Anggaran Pendapatan dan Belanja Daerah (APBD) yang langsung maupun tidak langsung mencerminkan kemampuan pemerintah daerah dalam membiayai pelaksanaan tugas pemerintah, pembangunan, dan pelayanan sosial masyarakat. Pengelolaan keuangan daerah sangat mempengaruhi perekonomian masyarakat, jika pengelolaannya sesuai dengan kondisi yang dihadapi maka dapat meningkatkan pertumbuhan ekonomi. Namun Wibowo (2008) menyatakan bahwa dampak terhadap pembangunan akan bergantung pada ruang dan waktu sehingga dampak positif yang terjadi pada suatu daerah dalam periode tertentu belum bisa dijadikan tolak ukur bagi daerah lain pada waktu yang sama.

Pengelolaan keuangan daerah sebaiknya juga diikuti dengan peningkatan pelayanan publik sebagai bentuk pertanggungjawaban dengan cara mengoptimalkan belanja secara efektif dan efisien sehingga dapat meningkatkan kesejahteraan masyarakat serta mencapai tujuan pembangunan. Pelayanan publik dapat dilihat dari besarnya belanja pemerintah di suatu daerah yang juga menggambarkan posisi fiskal suatu daerah. Posisi fiskal yang lebih kuat akan meningkatkan layanan kota dan membuat siklus pengembangan terus bergerak maju (World Bank dalam Landiyanto, 2005). Oleh karena itu, peneliti tertarik untuk menganalisis kemampuan keuangan daerah dan posisi fiskal serta pengaruhnya terhadap pertumbuhan ekonomi pada kabupaten/kota di Provinsi Kalimantan Barat.

\section{TINJAUAN PUSTAKA}

Berdasarkan Undang-Undang No. 32 tahun 2004 tentang Pemerintah Daerah pasal 1 ayat 5 , otonomi daerah adalah hak, wewenang, dan kewajiban daerah otonom untuk mengatur dan mengurus sendiri urusan pemerintahan dan kepentingan masyarakat setempat sesuai dengan peraturan perundang-undangan. Mardiasmo (2009) berpendapat bahwa pelaksanaan otonomi daerah di Indonesia dapat dipandang sebagai suatu strategi yang memiliki tujuan ganda. Pertama, pemberian otonomi daerah merupakan strategi untuk merespon tuntutan masyarakat daerah terhadap tiga permasalahan utama, yaitu sharing of power, distribution income, dan kemandirian sistem menajemen di daerah. Kedua, otonomi daerah dimaksudkan sebagai strategi untuk memperkuat perekonomian daerah dalam rangka memperkokoh perekonomian nasional untuk menghadapi era perdagangan bebas.

Berdasarkan Undang-Undang No.33 tahun 2004 tentang Perimbangan Keuangan antara Pusat dan Daerah pasal 1 ayat 8, desentralisasi adalah penyerahan wewenang pemerintahan oleh Pemerintah kepada daerah otonom untuk mengatur dan mengurus urusan pemerintahan dalam sistem Negara Kesatuan Republik Indonesia. Secara garis besar, kebijakan desentralisasi menurut Soleh dan Heru (2010) dibedakan menjadi tiga, yaitu desentralisasi politik, desentralisasi administrasi dan desentralisasi fiskal. Menurut 
Halim (2004) dalam Thesaurianto (2007) desentralisasi fiskal memiliki berbagai keuntungan yakni meningkatnya demokrasi akar rumput, perlindungan atas kebebasan dan hak asasi manusia, meningkatkan efisiensi melalui pendelegasian kewenangan, meningkatkan kualitas pelayanan dan meningkatkan pembangunan ekonomi dan sosial.

APBD merupakan instrumen kebijakan utama bagi pemerintah daerah, yang menduduki posisi sentral dalam upaya pengembangan kapabilitas dan efktivitas pemerintah daerah. Struktur anggaran daerah merupakan satu kesatuan yang terdiri dari:

1. Pendapatan daerah, yang terdiri dari: pendapatan asli daerah (PAD); dana perimbangan, meliputi bagian hasil pajak dan bukan pajak, dana alokasi umum (DAU), dana alokasi khusus (DAK); pinjaman daerah; lain-lain penerimaan daerah yang sah.

2. Belanja daerah, berdasarkan kelompok belanja dibedakan menjadi belanja tidak langsung dan belanja langsung.

3. Pembiayaan, yaitu transaksi keuangan daerah yang dimaksudkan untuk menutup selisih antara pendapatan daerah dan belanja daerah.

Penyelenggaraan fungsi pemerintahan daerah akan terlaksana secara optimal apabila penyelenggaraan urusan pemerintahan diikuti dengan pemberian sumber-sumber penerimaan yang cukup kepada daerah, dengan mengacu kepada Undang-Undang yang mengatur Perimbangan Keuangan antara Pemerintah Pusat dan Pemerintahan Daerah, dimana besarnya disesuaikan dan diselaraskan dengan pembagian kewenangan antara Pemerintah dan Daerah. Semua sumber keuangan yang melekat pada setiap urusan pemerintah yang diserahkan kepada daerah menjadi sumber keuangan daerah.

Sumber penerimaan daerah yang berasal dari partisipasi masyarakat suatu daerah yang disebut juga pendapatan daerah sendiri (PDS) adalah pendapatan asli daerah (PAD) dan bagi hasil pajak dan bukan pajak (BHPBP). PAD terdiri dari pajak daerah, retribusi daerah, hasil perusahaan milik daerah serta hasil pengelolaan kekayaan daerah yang dipisahkan dan lain-lain PAD yang sah. Kemampuan keuangan daerah dapat diukur dengan derajat desentralisasi fiskal antara pemerintah pusat dan daerah atau dengan derajat kemandirian daerah.

Posisi fiskal daerah merupakan indikator yang menunjukkan bagaimana posisi atau keadaan suatu daerah dibandingkan daerah lainnya, dengan diketahuinya posisi fiskal suatu daerah maka diharapkan kebijakan yang diambil sesuai dengan keadaan daerah tersebut sehingga menjadi lebih efektif dan efisien. Posisi fiskal kabupaten/kota menurut Reksohadiprodjo (2001:156-157) dapat diketahui melalui:

- kinerja Pendapatan Asli Daerah (tax performance), yang menggambarkan upaya pajak dalam perekonomian, semakin tinggi hasilnya maka semakin besar upaya pajaknya 
- kapasitas fiskal daerah (fiscal capacity), yang menggambarkan kemampuan masyarakat suatu daerah untuk berpartisipasi meningkatkan PAD, semakin tinggi hasilnya maka semakin besar kapasitasnya

- kebutuhan fiskal ( fiscal need), yang menggambarkan pelayanan publik di suatu daerah, semakin tinggi hasilnya maka kebutuhan fiskalnya semakin tinggi

- elastisitas PAD terhadap PDRB yaitu rasio antara pertumbuhan PAD dengan pertumbuhan PDRB, semakin elastis PAD satu daerah maka struktur PAD di daerah tersebut semakin baik.

Pertumbuhan ekonomi dari sudut tinjauan ekonomi dapat direfleksikan oleh pertumbuhan Produk Domestik Regional Bruto (PDRB) atas dasar harga konstan. PDRB merupakan penjumlahan dari semua barang dan jasa akhir mencakup semua nilai tambah yang dihasilkan oleh daerah dalam periode satu tahun. Pertumbuhan ekonomi merupakan salah satu indikator yang dapat menggambarkan perkembangan perekonomian dalam suatu daerah.

Masalah pertumbuhan ekonomi jangka panjang dapat dibedakan menjadi tiga aspek, aspek pertama yaitu perbedaan di antara tingkat pertumbuhan potensial yang dapat dicapai dan tingkat pertumbuhan yang sebenarnya tercapai. Aspek kedua adalah meningkatkan potensi pertumbuhan itu sendiri. Aspek ketiga mengenai keteguhan pertumbuhan ekonomi yang berlaku dari satu tahun ke tahun lainnya.

\subsection{Penelitian Terdahulu dan Pengembangan Hipotesis}

Kemampuan keuangan yang tinggi dalam suatu daerah diharapkan dapat meningkatan pertumbuhan ekonomi, salah satu indikator yang dapat menggambarkan kemampuan keuangan daerah adalah derajat desentralisasi fiskal. Menurut Simanjuntak dan Imam (2012), desentralisasi fiskal merupakan salah satu bentuk desentralisasi yang diidentifikasi mempunyai peranan penting dalam rangka pencapaian kesejahteraan masyarakat. Mardiasmo (2007) dalam Zulyanto (2010) berpendapat bahwa besarnya transfer dana di daerah seharusnya memiliki korelasi yang positif terhadap upaya peningkatan kesejahteraan masyarakat, artinya ada keyakinan yang kuat dari peminat desentralisasi untuk terus melaksanakan desentralisasi fiskal guna mendorong pertumbuhan ekonomi di berbagai wilayah. Desentralisasi fiskal berpotensi memberikan kontribusi dalam bentuk peningkatan efisiensi pemerintahan dan laju pertumbuhan ekonomi (Oates, 1993 dalam Wibowo, 2008).

Beberapa penelitian yang berkaitan dengan pengaruh kemampuan keuangan daerah terhadap pertumbuhan ekonomi antara lain adalah penelitian Pujiati yang menemukan bahwa PAD, DBH dan tenaga kerja di 6 kabupaten/kota di Semarang tahun 2002-2006 mempunyai pengaruh positif dan signifikan terhadap pertumbuhan ekonomi sedangkan DAU berpengaruh negatif dan signifikan terhadap pertumbuhan ekonomi. 
Wibowo (2008) yang meneliti 29 provinsi di Indonesia pada tahun 1999-2004 menemukan indikator ekonomi yaitu rasio PAD berpengaruh secara negatif terhadap pertumbuhan ekonomi sedangkan pendapatan daerah kotor dan netto mempunyai hubungan positif dan signifikan terhadap pertumbuhan ekonomi.

Zulyanto (2010) meneliti tentang implementasi derajat desentralisasi fiskal pengaruh desentralisasi fiskal yang diukur dengan rasio antara total belanja pemerintah daerah dengan total belanja pemerintah pusat serta variabel kontrol initial level of PDRB, pertumbuhan penduduk, investasi dan human capital terhadap pertumbuhan ekonomi yang diproksikan dengan PDRB riil perkapita di Provinsi Bengkulu. Penelitian ini menemukan bahwa rata-rata derajat desentralisasi fiskal kabupaten/kota di Provinsi Bengkulu lebih rendah dari rata-rata nasional, variabel desentralisasi fiskal, investasi dan human capital berpengaruh positif dan signifikan terhadap pertumbuhan ekonomi, initial level of PDRB berpengaruh negatif dan signifikan dan pertumbuhan penduduk berpengaruh negatif tetapi belum signifikan terhadap pertumbuhan ekonomi.

Berdasarkan teori dan penelitian-penelitian sebelumnya maka kemampuan keuangan daerah dalam penelitian ini dilihat dari proporsi pendapatan daerah sendiri (PDS) sehingga hipotesisnya adalah:

$\mathrm{H}_{0}$ : Proporsi pendapatan daerah sendiri (PDS) tidak berpengaruh positif dan signifikan terhadap pertumbuhan ekonomi

$\mathrm{H}_{1}$ : Proporsi pendapatan daerah sendiri (PDS) berpengaruh positif dan signifikan terhadap pertumbuhan ekonomi

Posisi fiskal suatu daerah juga diharapkan dapat mendukung pertumbuhan ekonomi. Posisi fiskal suatu daerah dapat dilihat dari belanja pemerintah. Menurut teori Keynes dalam Yacoub dan Resty (2011), belanja pemerintah merupakan salah satu mesin pendorong pertumbuhan ekonomi. Sukirno (2010) juga menyatakan bahwa pengeluaran pemerintah akan meningkatkan keseluruhan pembelanjaan agregrat. Simanjuntak dan Imam (2012) mengungkapkan bahwa proses pengeluaran pemerintah daerah dalam mempengaruhi kesejahteraan hidup masyarakat dapat dijelaskan dengan proses multiplier, semakin besar multiplier yang diciptakan maka semakin besar pula perubahan yang dapat diciptakan dalam keseimbangan pendapatan nasional. Tujuan utama pengeluaran anggaran adalah tercapainya tingkat kesejahteraan masyarakat dimana pemerintah daerah sebagai pelaksana pengalokasian anggaran dapat menetapkan kebijakan skala prioritas terhadap sektor-sektor layanan masyarakat yang penting dalam pencapaian kesejahteraan.

Beberapa penelitan terdahulu yang berkaitan antara lain adalah penelitian Rahayu (2004) yang menemukan bahwa investasi pemerintah daerah berupa pengeluaran pembangunan menunjukkan kontribusi positif yang signifikan secara statistik dan mengestimasi multiplier dari investasi pemerintah lokal, sedangkan konsumsi pemerintah dan tenaga kerja memberikan efek yang positif tapi tidak signifikan. Disisi lain, koefisien 
dari penerimaan pemerintah daerah dari pajak dan bukan pajak memberikan efek negatif yang signifikan terhadap pertumbuhan ekonomi regional di wilayah Surakarta pada tahun 1987-2000.

Purba (2006) yang meneliti tentang faktor-faktor yang mempengaruhi pertumbuhan ekonomi di Kabupaten Simalungun tahun 1976-2003 menemukan hasil bahwa pengeluaran pembangunan berpengaruh negatif dan pengeluaran rutin berpengaruh positif namun keduanya tidak memberikan pengaruh yang berarti secara stastisik sedangkan jumlah tenaga kerja dan pertumbuhan ekonomi sebelumnya memberikan pengaruh yang positif dan signifikan terhadap pertumbuhan ekonomi.

Penelitian Sodik (2007) terhadap 26 provinsi di Indonesia pada tahun 1993-2003 menemukan bahwa investasi swasta tidak berpengaruh terhadap pertumbuhan ekonomi, variabel pengeluaran pemerintah daerah yang terdiri dari pengeluaran rutin dan pengeluaran pembangunan berpengaruh dan signifikan dengan tanda positif terhadap pertumbuhan ekonomi regional, sedangkan ekspor netto dan angkatan kerja berpengaruh negatif dan signifikan terhadap pertumbuhan ekonomi.

Abrar (2010) yang meneliti Provinsi Aceh pada tahun 2001-2006 menemukan hubungan PAD dengan PDRB menunjukkan fungsi kuadratik yang perlu diwaspadai posisinya di masa depan karena pada data tahun terakhir telah menunjukkan kondisi yang semakin menurun dan hubungan belanja pembangunan dengan PDRB menunjukkan fungsi kuadratik yang perlu diwaspadai posisinya di masa depan walaupun pada data tahun terakhir telah menunjukkan kondisi yang puncak. Jika belanja ini tidak dimanfaatkan kepada kegiatan ekonomi produktif maka dikhawatirkan akan mengalami dampak negatif bagi pertumbuhan ekonomi.

Berdasarkan teori dan penelitian-penelitian sebelumnya maka posisi fiskal dalam penelitian ini dilihat dari proporsi belanja langsung per kapita sehingga hipotesisnya adalah:

$\mathrm{H}_{0}$ : Proporsi belanja langsung per kapita tidak berpengaruh positif dan signifikan terhadap pertumbuhan ekonomi

$\mathrm{H}_{2}$ : Proporsi belanja langsung per kapita berpengaruh positif dan signifikan terhadap pertumbuhan ekonomi

\subsection{Kerangka Konseptual}

Proporsi pendapatan daerah sendiri (PDS) merupakan penerimaan yang berasal dari partisipasi masyarakat daerah sendiri. Pengoptimalan penerimaan hendaknya juga didukung dengan upaya untuk meningkatkan kualitas pelayanan publik yang dapat terlihat dari belanja pemerintah daerah. Belanja langsung sebaiknya mempunyai porsi yang lebih besar karena dampaknya dapat dirasakan oleh masyarakat lewat efek 
multiplier. Belanja langsung per kapita akan menggambarkan tingkat kesejahteraan masyarakat. Peningkatan proporsi PDS dan belanja langsung per kapita diharapkan dapat mendorong pertumbuhan ekonomi daerah yang merupakan salah satu indikator keberhasilan pembangunan ekonomi dalam suatu daerah untuk lebih jelasnya dapat dilihat pada gambar berikut:

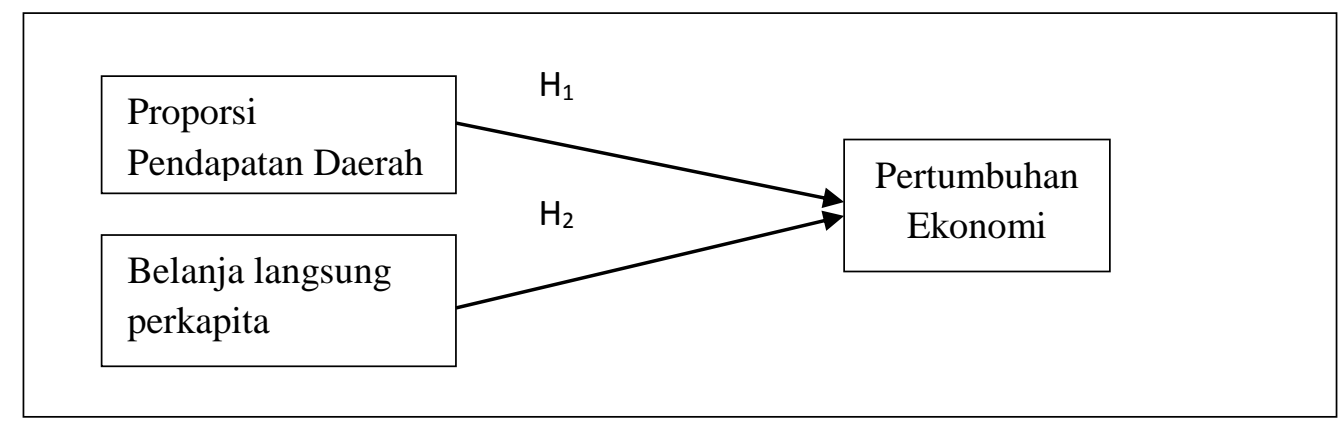

\section{Gambar 1. Model Konseptual}

\section{METODE PENELITIAN}

\subsection{Jenis Penelitian}

Jenis penelitian yang digunakan adalah penelitian kuantitatif. Menurut Indriantoro dan Bambang (2014), penelitian kuantitatif menekankan pada pengujian teori melalui pengukuran variabel penelitian dengan angka dan melakukan analisis data dengan prosedur statistik. Dalam penelitian ini, yang ingin diuji adalah pengaruh kemampuan keuangan dan posisi fiskal terhadap pertumbuhan ekonomi.

\subsection{Sumber dan Jenis Data}

Data yang diteliti merupakan data sekunder, yaitu data APBD kabupaten/kota seKalimantan Barat, data jumlah penduduk serta data PDRB kabupaten/kota di provinsi Kalimantan Barat yang diperoleh dari BPS Provinsi Kalimantan Barat. Jenis data yang digunakan dalam penelitian ini adalah data panel yaitu gabungan data cross section ( 12 kabupaten/kota di Kalimantan Barat) dengan time series (tahun 2006 sampai tahun 2010) sehingga tersedia 60 data yang dapat diobservasi dalam penelitian ini.

\subsection{Alat Analisis}

Untuk mengetahui kemampuan keuangan kabupaten/kota di Kalimantan Barat tahun 2006-2010 digunakan derajat desentralisasi fiskal dari sisi penerimaan karena dianggap dapat menggambarkan peran pemerintah daerah dan pemerintah pusat, yang 
dilakukan dengan langkah-langkah yang diadaptasi dari Reksohadiprodjo (2001) sebagai berikut:

1) Menghitung proporsi PAD

Proporsi PAD $=\frac{\text { Pendapatan Asli Daerah }(P A D)}{\text { Total Penerimaan Daerah }(T P D)}$

2) Menghitung proporsi BHPBP

Proporsi B HPBP $=\frac{\text { Bagi Hasil Pajak dan Bukan Pajak wntuk Daerah }(B H P B P)}{\text { Total Penerimaan Daerah }(T P D)}$

3) Menghitung proporsi Sumbangan Daerah

Proporsi sumbangan daerah $=\frac{\text { Sumbangan Daerah }(S B)}{\text { Total Penerimaan Daerah (TPD) }}$

$\mathrm{TPD}=\mathrm{PAD}+\mathrm{BHPBP}+\mathrm{SB}$

Pola hubungan dan tingkat kemandirian daerah dapat dilihat pada tabel berikut:

Tabel 1. Pola Hubungan dan Tingkat kemandirian Daerah

\begin{tabular}{|c|c|c|c|}
\hline $\begin{array}{l}\text { Kemampuan } \\
\text { Keuangan }\end{array}$ & $\begin{array}{c}\text { Kemandirian } \\
(\%)\end{array}$ & $\begin{array}{c}\text { Pola } \\
\text { Hubungan }\end{array}$ & Keterangan \\
\hline Rendah sekali & $0-<25$ & Instruktif & $\begin{array}{l}\text { Peranan pemerintah pusat lebih dominan di- } \\
\text { bandingkan dengan kemandirian daerah, sehingga } \\
\text { daerah tidak mampu melaksanakan otonomi daerah }\end{array}$ \\
\hline Rendah & $25-<50$ & Konsultatif & $\begin{array}{l}\text { Campur tangan pemerintah pusat mulai berkurang, } \\
\text { dengan demikian daerah dianggap sedikit mampu } \\
\text { melaksanakan otonomi daerah }\end{array}$ \\
\hline Sedang & $50-<75$ & Partisipatif & $\begin{array}{l}\text { Peran pemerintah pusat semakin berkurang, tingkat } \\
\text { kemandirian daerah mendekati mampu melaksanakan } \\
\text { urusan otonomi daerah }\end{array}$ \\
\hline Tinggi & $75-<100$ & Delegatif & $\begin{array}{l}\text { Campur tangan pemerintah pusat tidak ada lagi } \\
\text { karena daerah benar-benar mampu melaksanakan } \\
\text { urusan otonomi daerah }\end{array}$ \\
\hline
\end{tabular}

Sumber : diadaptasi dari Halim (2004) dalam Wati (2011)

Untuk mengetahui posisi fiskal kabupaten/kota di Kalimantan Barat tahun 20062010 dalam penelitian ini mengacu pada Reksohadiprodjo (2001) karena dilihat dari banyak sisi, yang dilakukan dengan langkah-langkah sebagai berikut:

1) Menghitung kebutuhan fiskal (fiscal need) dengan menghitung Indeks Pelayanan Publik per Kapita (IPPP)

$\mathrm{SKF}=\frac{\text { Iumlah belanja langsung/jumlah penduduk }}{\text { KKabupaten Kotamadya }}$ 
$\mathrm{IPPP}=\frac{\text { Pengelwaran Aktual per kapita untuk jasa-jasa publik (PPP) }}{\text { Standar Kebutwhan Fiskal Daerah }(\text { SKF })} \times 100 \%$

$\mathrm{PPP}=$ Jumlah belanja langsung per kapita masing-masing daerah.

Kalau hasilnya tinggi, kebutuhan fiskalnya besar.

2) Menghitung kapasitas fiskal (fiscal capacity)

$\mathrm{KF}_{\mathrm{s}}=\frac{\sum \text { PDRB /penduduk }}{\sum \text { Kabupaten dan Kotamadya }}$
$\mathrm{C}_{\mathrm{j}}=\frac{\text { Produk Domestik Bruto (PDRB }) / \sum \text { penduduk }}{\text { Kapasitas Fiskal Standar }\left(K F_{s}\right)} \times 100 \%$

Kalau hasilnya tinggi, kapasitas fiskalnya tinggi.

3) Menghitung elastisitas

Cara lain menentukan posisi fiskal daerah adalah dengan mencari koefisien elastisitas PAD terhadap PDRB. Semakin elastis PAD suatu daerah, maka struktur PAD di daerah tersebut semakin baik.

$\mathrm{e}=\frac{\triangle P A D}{\triangle P D R B} \cdot \frac{P D R B}{P A D}$

e = elastisitas

Tingkat elastisitas yang diadaptasi dari Herlambang, et al. (2007) digolongkan menjadi:

E > 1 berarti bersifat elastis, jika PDRB meningkat sebesar 1\% maka PAD meningkat lebih besar dari $1 \%$.

$\mathrm{E}<1$ berarti bersifat inelastis, jika PDRB meningkat sebesar $1 \%$ maka PAD meningkat kurang dari $1 \%$.

$\mathrm{E}=1$ berarti bersifat unileter elastis, jika PDRB meningkat sebesar $1 \%$ maka PAD juga meningkat sebesar $1 \%$.

4) Menghitung upaya fiskal (tax effort)

$\mathrm{UPPAD}_{\mathrm{j}}=\frac{P A D_{j}}{P D R B_{j}}$

Selanjutnya dihitung tingkat PAD Standar $\left(\mathrm{TPAD}_{\mathrm{s}}\right)$ yaitu:

$\mathrm{TPAD}_{\mathrm{s}}=\frac{\sum P A D / P D R B}{\sum \text { Kabupaten dan Kota }}$

Sedang Indeks Kinerja PAD

$\mathrm{IKPAD}=\frac{U P P A D}{T P A D_{s}} \times 100 \%$ 
Makin tinggi hasilnya, makin besar upaya fiskalnya. Ini juga menunjukkan posisi fiskal daerah.

Untuk menguji dan menganalisis pengaruh kemampuan keuangan daerah dan posisi fiskal terhadap pertumbuhan ekonomi digunakan analisis regresi berganda (Multiple Regression Analysis) dengan menggunakan program Eviews 6. Kemampuan keuangan daerah dilihat dari sisi penerimaan yang diproksikan dengan rasio antara pendapatan daerah sendiri (PAD dan BHPBP) dengan total penerimaan daerah, sedangkan posisi fiskal dilihat sisi pengeluaran yang diproksikan dengan belanja langsung per kapita.

Dengan demikian spesifikasi model menjadi sebagai berikut:

$$
\mathrm{Y}=\alpha+\beta_{1} \mathrm{X}_{1}+\beta_{2} \mathrm{X}_{2}+\mathrm{e}_{\mathrm{it}}
$$

Dimana:

$\mathrm{Y}=$ Pertumbuhan ekonomi

$\mathrm{X}_{1}=$ Proporsi pendapatan daerah sendiri

$\mathrm{X}_{2}=$ Belanja langsung per kapita

Untuk mengestimasi parameter model dengan data panel, terdapat beberapa teknik yang ditawarkan (Nachrowi dan Hardius, 2006), yaitu:

1. Ordinary Least Square (OLS)

2. Model Efek Tetap (Fixed Effect)

3. Model Efek Random (Random Effect)

\subsection{Pengujian Model}

Untuk memilih model yang tepat, Nackrowi dan Hardius (2006) menyarankan beberapa uji yang perlu dilakukan, yaitu menggunakan uji signifikansi Fixed Effect (Uji F) dan uji Hausman. Widarjono (2009) menambahkan uji Lagrange Multiplier (LM) untuk memilih model.

1. Uji Signifikansi Fixed Effect (Uji F) digunakan untuk mengetahui apakah teknik regresi data panel dengan model efek tetap (MET) lebih baik dari model regresi data panel OLS.

2. Uji Hausman digunakan untuk memilih diantara model efek tetap (MET) atau model efek random (MER) dapat digunakan uji Hausman.

3. Uji Lagrange Multiplier (LM) digunakan untuk mengetahui apakah model Random Effect (MER) lebih baik dari OLS. 


\subsection{Pengujian Kriteria Statistik}

Pengujian kriteria statistik melibatkan ukuran kesesuaian model yang digunakan (goodness of fit) dan uji signifikansi, baik pengujian secara parsial (uji t) maupun pengujian secara simultan (uji F).

1. Koefisien Determinasi $\left(\mathrm{R}^{2}\right)$, yaitu suatu ukuran yang menjelaskan besar variasi variabel terikat (dependen) dapat diterangkan oleh variabel bebas (independen).

2. Uji $\mathrm{F}$ atau pengujian secara simultan digunakan untuk melihat pengaruh variabelvariabel independen secara keseluruhan atau simultan terhadap variabel dependen.

3. Uji t atau pengujian secara parsial digunakan untuk melihat signifikansi pengaruh variabel independen secara individu terhadap variabel dependen dengan manganggap variabel lain bersifat konstan.

\section{TEMUAN DAN PEMBAHASAN}

\subsection{Kemampuan Keuangan Kabupaten/Kota di Provinsi Kalimantan Barat Proporsi PAD}

Pada tahun 2006-2010, rata-rata proporsi PAD tertinggi terdapat pada Kota Pontianak yaitu sebesar $12,10 \%$ sedangkan yang terendah terdapat pada Kabupaten Landak yaitu sebesar 2,27\%, hanya Kota Pontianak yang memiliki rata-rata proporsi PAD diatas rata-rata proporsi PAD kabupaten/kota se-Indonesia yaitu sebesar 7,98\%. Proporsi PAD tertinggi serta meningkat secara konsisten terdapat di Kota Pontianak yang didukung oleh tingginya pendapatan dari sumber pajak terutama dari pajak penerangan jalan. Sumber PAD yang didominasi dari selain pajak menyebabkan Kabupaten Landak mempunyai sumber pendapatan yang tidak tetap dan PAD cenderung kecil sehingga proporsi PAD lebih rendah dibandingkan kabupaten/kota lainnya di Provinsi Kalimantan Barat maupun se-Indonesia.

Menurut Soleh dan Heru (2010) pemerintah diharapkan dapat meningkatkan PAD untuk mengurangi ketergantungan terhadap pembiayaan dari pusat sehingga meningkatkan otonomi dan keleluasaan daerah namun dalam pelaksanaannya harus sesuai dengan tujuan otonomi daerah.

\section{Proporsi BHPBP}

Pada tahun 2006-2010, rata-rata proporsi BHPBP tertinggi terdapat pada Kota Pontianak yaitu sebesar $10,01 \%$ sedangkan yang terendah terdapat pada Kabupaten Sambas yaitu sebesar 5,86\%, rata-rata proporsi BHPBP kabupaten/kota di provinsi Kalimantan Barat masih dibawah rata-rata kabupaten/kota se-Indonesia yaitu sebesar 19,57\%. Rata-rata proporsi BHPBP Kota Pontianak lebih tinggi dibandingkan 
kabupaten/kota lainnya di Provinsi Kalimantan Barat disebabkan penerimaan baik dari bagi hasil pajak maupun bukan pajak yang meningkat tiap tahunnya sedangkan di Kabupaten Sambas proporsi BHPBP lebih rendah disebabkan karena sumber BHPBP baik dari pajak maupun bukan pajak dalam tiga tahun terakhir mengalami penurunan.

Peningkatan kemampuan keuangan daerah dengan pengoptimalan bagi hasil disamping menguntungkan pemerintah daerah juga akan menguntungkan pemerintah pusat karena jika potensinya besar maka dapat membantu mobilisasi penerimaan pusat. Proporsi BHPBP yang masih dibawah rata-rata kabupaten/kota se-Indonesia menunjukkan bahwa kabupaten/kota di Kalimantan Barat masih kurang membantu dalam mobilisasi penerimaan pusat.

\section{Proporsi PDS}

Proporsi pendapatan daerah sendiri (PDS) yang merupakan total penjumlahan PAD dan BHPBP menggambarkan penerimaan daerah yang berasal dari masyarakat daerah sendiri. PAD kabupaten/kota di Provinsi Kalimantan Barat pada tahun 2006 sampai 2010 walaupun telah ditambah dengan proporsi BHPBP jumlahnya masih rendah sekali yaitu bernilai dibawah $25 \%$ dimana terjadi pola hubungan instruktif yaitu kemampuan keuangan daerah yang rendah sekali sehingga sangat bergantung pada pemerintah pusat dan dianggap tidak mampu melaksanakan otonomi daerah (Halim, 2004 dalam Wati, 2011). Semakin tinggi proporsi PDS maka semakin besar penerimaan daerah yang bersumber dari masyarakat daerah sendiri.

Rata-rata proporsi PDS kabupaten/kota di Provinsi Kalimantan Barat yang paling tinggi terdapat di Kota Pontianak yaitu sebesar 22,11\% dan yang paling rendah terdapat di Kabupaten Sambas yaitu sebesar 9,70\%, angka ini masih jauh dibawah rata-rata kabupaten/kota se-Indonesia yaitu sebesar 27,55\%. Hasil ini menunjukkan bahwa masyarakat kabupaten/kota di Provinsi Kalimantan Barat masih kurang berpartisipasi dalam pengoptimalan penerimaan daerah sehingga sumber penerimaan daerah kabupaten/kota di Kalimantan Barat mayoritas berasal dari luar daerah.

Kemampuan keuangan kabupaten/kota di Kalimantan Barat tergolong sebagai pola instruktif dimana kemampuan keuangan masih sangat rendah sekali sehingga sangat bergantung pada pemerintah pusat dan dianggap tidak mampu melaksanakan otonomi daerah. Beberapa faktor penyebab utama ketergantungan fiskal menurut Kuncoro (2004) adalah kurang berperannya perusahaan daerah sebagai sumber pendapatan daerah, tingginya derajat sentralisasi dalam bidang perpajakan, hanya sedikit pajak daerah yang bisa diandalkan sebagai sumber penerimaan, adanya kekhawatiran terjadi disentegrasi dan separatisme dan kelemahan dalam pemberian subsidi. 


\section{Proporsi Sumbangan Daerah}

Pada tahun 2006-2010, rata-rata proporsi sumbangan daerah tertinggi terdapat pada Kabupaten Sambas yaitu sebesar 90,30\% sedangkan yang terendah terdapat pada Kota Pontianak yaitu sebesar 77,89\%, angka ini masih di atas rata-rata proporsi sumbangan daerah kabupaten/kota se-Indonesia. Secara umum hal ini menunjukkan bahwa sumber penyumbang terbesar untuk penerimaan daerah kabupaten/kota di Provinsi Kalimantan Barat adalah sumbangan yang diterima daerah dari pemerintah puat baik berupa DAU atau DAK, yang berarti bahwa pemerintah pusat masih mempunyai peran yang besar.

\section{Posisi Fiskal Kabupaten/Kota di Provinsi Kalimantan Barat Kebutuhan Fiskal}

Rata-rata kebutuhan fiskal daerah tertinggi terdapat pada Kabupaten Kapuas Hulu yaitu sebesar $175,15 \%$ yang berarti belanja yang dikeluarkan untuk pembangunan di Kabupaten Kapuas Hulu lebih tinggi di bandingkan kabupaten/kota lainnya sedangkan yang terendah terdapat pada Kabupaten Sambas yaitu sebesar 55,90\%. Posisi fiskal daerah yang tinggi jika dilihat dari kebutuhan fiskal terdapat pada Kabupaten Bengkayang, Kabupaten Ketapang, Kabupaten Kapuas Hulu, Kabupaten Sekadau, Kabupaten Melawi dan Kota Singkawang karena berada di atas standar kebutuhan fiskal daerah yang menunjukkan besarnya pembiayaan untuk pembangunan sehingga diharapkan masyarakat dapat merasakan langsung manfaatnya agar tercipta efek yang luas terhadap perekonomian.

\section{Kapasitas Fiskal}

Rata-rata kapasitas fiskal daerah tertinggi terdapat pada Kota Pontianak yaitu sebesar 184,92\% yang berarti kemampuan masyarakat di Kota Pontianak lebih tinggi dibandingkan kabupaten/kota lainnya sedangkan yang terendah terdapat pada Kabupaten Melawi yaitu sebesar 46,26\%, yang disebabkan karena rendahnya PDRB per kapita. Posisi fiskal yang tinggi jika dilihat dari kapasitas fiskal terdapat pada Kabupaten Sanggau, Kabupaten Ketapang, Kabupaten Sintang, Kota Pontianak dan Kota Singkawang karena berada di atas standar kapasitas daerah. Hal ini menunjukkan tingginya kemampuan masyarakat untuk mendukung peningkatan PAD khususnya dalam membayar pajak dan retribusi.

\section{Celah Fiskal}

Celah fiskal merupakan selisih antara kebutuhan daerah dengan kapasitas daerah. Kebutuhan daerah untuk mengetahui celah fiskal dalam penelitian ini dilihat dari indeks belanja per kapita yang meliputi belanja langsung maupun tidak langsung sedangkan kapasitas daerah dilihat dari indeks PDRB per kapita. 
Kabupaten Sambas, Kabupaten Pontianak, Kabupaten Sanggau, Kabupaten Ketapang, Kabupaten Sintang, Kota Pontianak, dan Kota Singkawang memiliki nilai celah fiskal yang negatif, yang menunjukkan bahwa daerah tersebut memiliki potensi sumber pembiayaan yang lebih besar daripada belanja daerah. Celah fiskal yang bernilai positif terdapat pada Kabupaten Bengkayang, Kabupaten Landak, Kabupaten Kapuas Hulu, Kabupaten Sekadau, dan Kabupaten Melawi yang menunjukkan potensi sumber pembiayaan lebih kecil daripada belanja daerah. Celah fiskal yang bernilai negatif menunjukkan kekurangan sumber pembiayaan yang diharapkan dapat tertutupi dengan dana transfer dari pemerintah pusat.

\section{Elastisitas}

Pada tahun 2006-2010 ada 9 kabupaten/kota yang memiliki elastisitas lebih dari 1 dimana rata-rata elastisitas tertinggi terdapat pada Kabupaten Melawi yaitu sebesar 4,98\% sedangkan 3 kabupaten memiliki elastisitas kurang dari 1 dimana yang terendah terdapat pada Kabupaten Pontianak yaitu sebesar 0,10\%. Elastisitas dapat menentukan posisi fiskal suatu daerah, semakin elastis PAD suatu daerah maka struktur PAD nya semakin baik karena peningkatan PAD lebih besar dari peningkatan PDRB. PAD yang elastis di Provinsi Kalimantan Barat terdapat pada Kabupaten Sambas, Kabupaten Bengkayang, Kabupaten Sanggau, Kabupaten Ketapang, Kabupaten Kapuas Hulu, Kabupaten Sekadau, Kabupaten Melawi, Kota Pontianak dan Kota Singkawang.

\section{Upaya fiskal}

Rata-rata upaya fiskal daerah tertinggi terdapat pada Kabupaten Melawi yaitu sebesar 0,013 sedangkan yang terendah terdapat pada Kabupaten Landak yaitu sebesar 0,004. Hasil ini menunjukkan rendahnya peran PAD terutama pajak dan retribusi daerah terhadap perekonomian daerah kabupaten/kota di Provinsi Kalimantan Barat.

Rata-rata indeks kinerja PAD tertinggi terdapat pada Kabupaten Melawi yaitu sebesar $186,54 \%$ sedangkan yang terendah terdapat pada Kabupaten Landak yaitu sebesar 57,34\% yang disebabkan karena rendahnya upaya fiskal. Upaya fiskal yang lebih besar dibandingkan PAD standar menunjukkan posisi fiskal daerah yang tinggi yang terdapat di Kabupaten Sintang, Kabupaten Kapuas Hulu, Kabupaten Sekadau, Kabupaten Melawi dan Kota Singkawang.

\subsection{Pengaruh Kemampuan Keuangan dan Posisi Fiskal terhadap Pertumbuhan Ekonomi}

Uji $\mathrm{F}$ dilakukan untuk melihat pengaruh simultan pengaruh variabel bebas (independent) terhadap variabel terikat (dependent). Hasil analisa data menunjukkan 
bahwa nilai $F_{\text {hitung }}$ yang diperoleh adalah sebesar 13,427 dengan probabilitas sebesar 0,000. Jika dibandingkan dengan $\alpha=5 \%$, maka nilai probabilitas yang diperoleh lebih kecil dari $\alpha$ yang ditetapkan $(0,000<0,05)$. Dengan demikian kita dapat menolak $\mathrm{H}_{0}$ dan mengambil kesimpulan bahwa variabel proporsi PDS dengan belanja langsung per kapita secara simultan atau bersama-sama berpengaruh signifikan terhadap pertumbuhan ekonomi kabupaten/kota di Kalimantan Barat.

Tabel 3. Tabel Hasil Uji Statistik

\begin{tabular}{lcrrl}
\hline Variabel & Koefisien & t-statistik & Probability & Kesimpulan \\
\hline C & 9.146402 & 3.297298 & 0.0019 & Signifikan \\
LNPROPORSIPDS? & -0.113385 & -4.317889 & 0.0001 & Signifikan \\
LNBELANJALANGSUNG? & -0.373881 & -0.898116 & 0.3738 & Tidak Signifikan \\
R-squared & 0,791434 & & & \\
F-statistik & 13,42723 & & & \\
Prob (F-statistik) & 0,000000 & & & \\
\hline
\end{tabular}

Uji t digunakan untuk melihat pengaruh parsial masing-masing variabel bebas (independent) terhadap variabel terikat (dependent). Hasil analisis menunjukkan bahwa proporsi PDS dengan nilai thitung sebesar $-4,318$ dengan probabilitas sebesar $0,000(0,000$ $<0,05)$ maka $\mathrm{H}_{0}$ dapat ditolak sehingga proporsi PDS berpengaruh positif dan signifikan terhadap pertumbuhan ekonomi. Namun nilai koefisien sebesar -0,113 menunjukkan bahwa variabel proporsi PDS memiliki arah hubungan negatif dan signifikan terhadap pertumbuhan ekonomi.

Variabel belanja langsung per kapita dengan nilai thitung sebesar $-0,898$ dan probabilitas sebesar 0,374 jika dibandingkan dengan $\alpha=5 \%,(0,374>0,05)$ maka $\mathrm{H}_{0}$ tidak dapat ditolak sehingga belanja langsung per kapita tidak berpengaruh secara positif dan signifikan terhadap pertumbuhan ekonomi. Nilai koefisien sebesar -0,374 menunjukkan bahwa variabel belanja langsung per kapita di kabupaten/kota di Kalimantan Barat memiliki arah yang negatif. Pengaruh yang negatif baik dari proporsi PDS maupun belanja langsung per kapita terhadap pertumbuhan ekonomi secara statistik terjadi karena masih banyak kabupaten/kota yang berada di bawah rata-rata daerah. Pengaruh belanja langsung per kapita yang tidak signifikan terhadap pertumbuhan ekonomi secara statistik disebabkan adanya kesenjangan yang tinggi antara kabupaten yang memiliki belanja langsung per kapita terendah dengan kabupaten yang memiliki belanja langsung per kapita tertinggi.

\subsection{Pembahasan}

Dalam penelitian ini, variabel kemampuan keuangan daerah dilihat dari proporsi pendapatan daerah sendiri (PDS) karena menggambarkan pendapatan yang diperoleh dari partisipasi langsung masyarakat di daerah yang bersangkutan. Persamaan model 
yang didapat dari estimasi pengaruh kemampuan keuangan daerah dan posisi fiskal terhadap pertumbuhan ekonomi adalah sebagai berikut:

$$
Y=9,146402-0,113385 X_{1}-0,373881 X_{2}
$$

Pada kabupaten/kota di Provinsi Kalimantan Barat, proporsi PDS berpengaruh negatif terhadap pertumbuhan ekonomi. Proporsi PDS meningkat sebesar 10 persen maka akan menyebabkan pertumbuhan ekonomi turun sebesar 1,13 persen. Proporsi PDS yang terus meningkat walaupun sempat turun menjadi $13,01 \%$ pada tahun 2010 mengindikasikan adanya pengoptimalan sumber-sumber penerimaan daerah terutama yang bersumber dari pajak dan retribusi. Rata-rata proporsi pajak dan retribusi daerah kabupaten/kota di Provinsi Kalimantan Barat sempat menurun pada tahun 2007 namun meningkat kembali sampai tahun 2010. Proporsi bagi hasil pajak juga sempat menurun pada tahun 2008 namun meningkat kembali sampai tahun 2010.

Pertumbuhan ekonomi mengalami penurunan walaupun proporsi PDS meningkat dapat disebabkan karena kurangnya pelayanan publik yang diberikan kepada masyarakat, hal ini terlihat dari turunnya belanja langsung perkapita selama dua tahun terakhir. Mardiasmo (2002) dalam Abrar (2010) mengungkapkan dalam pelaksanaan pengoptimalan penerimaan daerah khususnya yang bersumber dari pajak dan retribusi harus diikuti dengan peningkatan kualitas layanan publik agar tidak memberikan sentimen negatif terhadap para pelaku ekonomi. Kasus ini juga dapat terjadi apabila pengelolaannya tidak dilaksanakan dengan baik seperti tidak adanya transparansi, aparatur daerah yang kurang menguasai ilmu keuangan publik, kurang berpengalaman dalam mengelola APBD, ataupun penyalahgunaan wewenang dan kekuasaan yang dimiliki.

Di Kalimantan Barat masih ada beberapa kabupaten/kota yang memiliki kapasitas fiskal yang tinggi namun upaya fiskalnya rendah. Hal ini menunjukkan adanya willingness to pay yang dapat memberikan dampak negatif terhadap pertumbuhan ekonomi. Menurut Simanjuntak dan Imam (2012), kepatuhan pajak merupakan salah satu komponen penting dalam meningkatkan penerimaan pajak. Kepatuhan pajak mencerminkan kesediaan dari individu untuk melaksanakan kewajiban perpajakannya, yang dipengaruhi oleh faktor ekonomi dan faktor non ekonomi. Pengenaan pajak harus efisien yang mensyaratkan alokasi dan distribusi dilaksanakan dengan bijaksana karena berkaitan langsung dengan kesejahteraan masyarakat. Pelaksanaan analisis positif dan pengukuran nilai diperlukan untuk mengukur efektivitas kebijakan pemerintah karena berhubungan langsung dengan masalah keadilan.

Prud'homme (1995) dalam Zulyanto (2010) menjelaskan beberapa penyebab kegagalan desentralisasi fiskal dalam mendorong pertumbuhan ekonomi, yaitu: 
1. Pemerintah daerah tidak dapat memenuhi preferensi masyarakat lokal baik karena politik maupun karena aparatur yang kurang termotivasi atau memenuhi syarat untuk tugas tersebut.

2. Meningkatnya korupsi karena umumnya politisi atau birokrat lokal lebih rentan karena mudah diakses oleh kelompok yang memiliki kepentingan, jika korupsi bisa dikurangi atau dihilangkan maka akan tercipta efisiensi alokasi dan mendorong pertumbuhan ekonomi.

3. Adanya sistem politik yang tidak demokratis sehingga premis dasar bahwa pemerintah daerah memiliki insentif yang lebih kuat untuk menyediakan barang publik lokal secara lebih efisien

Dalam penelitian ini posisi fiskal diproksikan dengan belanja langsung per kapita. Dari persamaan yang didapat diketahui bahwa jika belanja langsung per kapita mengalami peningkatan sebesar $10 \%$ maka pertumbuhan ekonomi akan menurun namun tidak signifikan yaitu sebesar $3,74 \%$ persen. Hubungan yang negatif namun tidak berpengaruh pada kabupaten/kota di Provinsi Kalimantan Barat dapat disebabkan karena pengelolaannya belum baik seperti kebijakan angaran belum sesuai dengan kebutuhan dan kondisi, selain itu juga dapat disebabkan karena belanja yang dikeluarkan tidak digunakan untuk kegiatan produktif yang terlihat dari realisasi investasi masih jauh dari rencana investasi yang telah ditetapkan sebelumnya sehingga tidak banyak memberikan efek multiplier terhadap pertumbuhan ekonomi. Belanja yang produktif diharapkan dapat membangun sarana dan prasarana untuk melancarkan investasi yang mempengaruhi perekonomian daerah. Rata-rata belanja langsung perkapita kabupaten/kota di Provinsi Kalimantan Barat yang menurun pada dua tahun terakhir juga menyebabkan belanja yang dikeluarkan menjadi tidak berpengaruh terhadap pertumbuhan

Hasil dari penelitian ini mendukung argumen Sodik (2007) yang menyatakan bahwa hubungan antara pengeluaran pemerintah dan pertumbuhan ekonomi tidak ada yang konsisten yaitu bisa positif atau negatif dan dampak dari pengeluaran publik akan tergantung kondisi penggunaannya. Beberapa penelitian yang mendukung hasil penelitian ini antara lain adalah penelitian yang dilakukan oleh Purba (2006) yang menemukan hubungan negatif antara pengeluaran pemerintah dengan pertumbuhan di Kabupaten Simalangun yang disebabkan karena kebijakan angaran yang dialokasikan untuk pengeluaran belum sesuai dengan kebutuhan dan kondisi yang ada. Barro (1990) dalam Sodik (2007) menemukan bahwa pengeluaran pemerintah yang tidak produktif berpengaruh negatif terhadap pertumbuhan serta terdapat adanya ketidak efisienan dalam manajemen secara keseluruhan dari anggaran pemerintah. 


\section{KESIMPULAN}

Kemampuan keuangan kabupaten/kota di Kalimantan Barat tahun 2006-2010 dilihat dari indikator desentralisasi fiskal masih sangat rendah. Hal ini terlihat dari ratarata proporsi PAD dan BHPBP kabupaten/kota di Kalimantan Barat yang masih jauh di bawah rata-rata kabupaten/kota se-Indonesia. Proporsi sumbangan daerah yang besar baik berupa DAU dan DAK menunjukkan peran pemerintah pusat masih sangat besar. Proporsi sumbangan daerah kabupaten/kota di Kalimantan Barat lebih tinggi daripada rata-rata kabupaten/kota se-Indonesia. Pemerintah daerah sebaiknya dapat mengoptimalkan sumber-sumber penerimaan yang berasal dari PAD sehingga mengurangi ketergantungan terhadap pemerintah pusat namun dalam pelaksanaannya harus sesuai dengan tujuan otonomi daerah.

Posisi fiskal yang dilihat dari empat indikator yaitu kebutuhan fiskal, kapasitas fiskal, elastisitas dan upaya fiskal menunjukkan bahwa Kota Singkawang memiliki posisi yang tinggi, Kabupaten Landak dan Kabupaten Pontianak memiliki posisi yang rendah sedangkan kabupaten/kota lainnya memiliki posisi yang berbeda. Hasil ini dapat menjadi pertimbangan bagi pemerintah daerah untuk mengambil kebijakan sesuai dengan posisi fiskalnya agar lebih efektif dan efisien.

Hasil pengujian model menemukan bahwa rasio PDS berpengaruh negatif dan signifikan terhadap pertumbuhan ekonomi dimana jika rasio PDS meningkat maka akan mengurangi pertumbuhan ekonomi sedangkan belanja langsung per kapita berpengaruh negatif namun tidak signifikan terhadap pertumbuhan ekonomi. Hal ini menunjukkan bahwa dalam usaha mengoptimalkan PDS sebaiknya diiringi dengan pengelolaan yang baik sehingga di respon positif oleh masyarakat serta peningkatan porsi belanja langsung untuk kegiatan produktif agar menimbulkan efek multiflier terhadap pertumbuhan ekonomi.

\section{DAFTAR PUSTAKA}

Abrar, M. (2010). Pengaruh Pendapatan Asli Daerah dan Belanja Modal terhadap Pertumbuhan Ekonomi Provinsi Aceh. Jurnal ekonomi dan Bisnis, 9 (1), 79-88.

Badan Pusat Statistik. Kalimantan Barat dalam Angka 2007-2011. Pontianak: Badan Pusat Statistik.

Badan Pusat Statistik. Statistik Keuangan Pemerintah Daerah Kabupaten/Kota 20062010. Pontianak: Badan Pusat Statistik.

Badan Pusat Statistik. Statistik Indonesia 2006-2010. Jakarta: Badan Pusat Statistik. 
BAPPENAS. (2003). Peta Kemampuan Keuangan Propinsi Dalam Era Otonomi Daerah

: Tinjauan atas Kinerja PAD dan Upaya yang Dilakukan Daerah. Direktorat Pengembangan Otonomi Daerah.

BAPPENAS, \& UNDP. (2008). Studi Evaluasi Dampak Pemekaran Daerah 2001-2007. BRIDGE.

Halim, \& Theresia. (2007). Seri Bunga Rampai Manajemen Keuangan Daerah Pengelolaan Keuangan Daerah (Ed. 2). Yogyakarta: UPP STIM YKPN.

Hendrik, Y. (2009). Analis Pengaruh Kapasitas Fiskal terhadap Pertumbuhan Ekonomi Kabupaten Dairi (Tesis yang tidak dipublikasikan), Universitas Sumatera Utara, Indonesia.

Sugiarto, Herlambang, T., Brastoro, Sudjana, R. \& Kelana, S. (2007). Ekonomi Mikro Sebuah Kajian Komprehensif (Ed. 2). Jakarta: PT Gramedia Pustaka Utama.

Indriantoro, N., \& Supomo, B. 2014. Metodologi Penelitian Bisnis untuk Akuntansi dan Manajemen. Yogyakarta: BPFE.

Juanda, B. (2009a). Metodologi Penelitian Ekonomi dan Bisnis. Edisi Kedua. Bandung: IPB Press.

Juanda, B. (2009b). Ekonometrika Pemodelan dan Pendugaan. Bandung: IPB Press.

Kuncoro, M. (2004). Otonomi dan Pembangunan Daerah; Reformasi, Perencanaan, Strategi dan Peluang. Jakarta: Erlangga.

Kurniawati R. T., \& Suhartono. (2010). Kemampuan Keuangan Daerah dalam Era Otonomi Daerah (Kasus Kabupaten BanyumasTahun 2003-2008). Laporan Penelitian Bidang Keilmuan.Lembaga Penelitian dan Pengabdian pada Masyarakat Universitas Terbuka.

Landiyanto, E. A. (2005). Kinerja Keuangan dan Strategi Pembangunan Kota di Era Otonomi Daerah:Studi Kasus Kota Surabaya, CURES Working Paper, No.05/01.

Mardiasmo. (2009). Otonomi dan Manajemen Keuangan Daerah. Edisi kedua. Yogyakarta: Penerbit Andi. 
Nachrowi, N. D., \& Usman, H. (2006). Pendekatan Populer dan Praktis Ekonometrika untuk Analisis Ekonomi dan Keuangan. Jakarta: Lembaga Penerbit Fakultas Ekonomi Universitas Indonesia.

Pujiati, A. (2008). Analisis Pertumbuhan Ekonomi di Karesidenan Semarang Era Desentralisasi Fiskal, Jurnal Ekonomi Pembangunan Kajian Ekonomi Negara Berkembang, 61-70.

Purba, A. (2006). Analisis Faktor-Faktor yang Mempengaruhi Pertumbuhan Ekonomi di Kabupaten Simalungun. (Tesis yang tidak dipublikasikan), Universitas Sumatera Utara, Indonesia.

Rahayu, S. A. T. (2004). Peranan Sektor Publik Lokal dalam Pertumbuhan Ekonomi Regional di Wilayah Surakarta (1987-2000), KINERJA, 8 (2), 133-147.

Reksohadiprodjo, S. (2001). Ekonomika Publik. Edisi Pertama. Yogyakarta: BPFE.

Ronald, A., \& Sarmiyatiningsih, D. (2010). Analisis Kinerja Keuangan dan Pertumbuhan Ekonomi Sebelum dan Sesudah Diberlakukannya Otonomi Daerah di Kabupaten Kulon Progo, EFEKTIF Jurnal Bisnis dan Ekonomi, 1(1), 31-42.

Rustiono, D., (2008). Analisis Pengaruh Investasi, Tenaga Kerja, dan Pengeluaran Pemerintah terhadap Pertumbuhan Ekonomi di Provinsi Jawa Tengah. (Tesis yang tidak dipublikasikan), Universitas Diponegoro, Indonesia.

Santoso, Budi, P., \& Rahayu, R. P. (2005). Analisis Pendapatan Asli Daerah (PAD) dan Faktor-Faktor yang Mempengaruhinya dalam Upaya Pelaksanaan Otonomi Daerah di Kabupaten Kediri, Dinamika Pembangunan, 2(1), 9-18.

Simanjutak, D. (2006). Analisis Pengaruh Pendapatan Asli Daerah terhadap Pertumbuhan Ekonomi di Kabupaten Labuhan Batu. (Tesis yang tidak dipublikasikan), Universitas Sumatera Utara, Indonesia.

Simanjuntak, T. H., \& Mukhlis, I. (2012). Dimensi Ekonomi Perpajakan dalam Pembangunan Ekonomi. Jakarta: Raih Asa Sukses.

Sodik, J. (2007). Pengeluaran Pemerintah dan Pertumbuhan Ekonomi Regional:Studi Kasus Data Panel di Indonesia, Jurnal Ekonomi Pembangunan Kajian Ekonomi Negara Berkembang, 12(1), 27-36. 
Soleh, C. \& Rochmansjah, H. (2010). Pengelolaan Keuangan dan Aset Daerah. Bandung: Fokusmedia.

Subiyanto, I. (2000). Metodologi Penelitian. Edisi Ketiga, Cetakan Kedua. Yogyakarta: UPP AMP YKPN.

Sugiyono. (2009). Metode Penelitian Bisnis. Cetakan ke-14. Bandung: Alfabeta.

Sukirno, S. (2000). Makroekonomi Modern Perkembangan Pemikiran Dari Klasik Hingga Keynesian Baru. Jakarta: PT RajaGrafindo

Sukirno, S. (2010). Makroekonomi Teori Pengantar. Jakarta: Rajawali Pers.

Suparmoko. (2002). Ekonomi Publik untuk Keuangan dan Pembangunan Daerah. Edisi 1. Yogyakarta: Andi Offset.

Suryana. (2000). Ekonomi Pembangunan. Edisi Pertama. Jakarta: Salemba Empat.

Thesaurianto, K. (2007). Analisis Pengelolaan Keuangan Daerah Terhadap Kemandirian Daerah. Tesis. (Tesis yang tidak dipublikasikan), Universitas Diponegoro, Indonesia.

Undang-Undang No.28 Tahun 2009 tentang Pajak Daerah dan Retribusi Daerah.

Undang-Undang No.32 Tahun 2004 tentang Pemerintah Daerah.

Undang-Undang No.33 Tahun 2004 tentang Perimbangan Keuangan antara Pemerintah Pusat dan Daerah.

Wati. (2011). Kemampuan Keuangan Daerah dalam Pelaksanaan Otonomi Daerah di Kabupaten Bengkayang Tahun 2005-2009. (Tesis yang tidak dipublikasikan), Universitas Tanjungpura, Indonesia.

Wibowo, P. (2008). Mencermati Dampak Desentralisasi Fiskal terhadap Pertumbuhan Ekonomi Daerah, Jurnal Keuangan Publik, 5(1), 55-83.

Widarjono, A. (2009). Ekonometrika Pengantar dan Aplikasinya (Ed. 3). Yogyakarta: Ekonisia. 
Yacoub, Y., \& Adelia, R. (2011). Pengaruh Belanja Publik dan Pertumbuhan Ekonomi terhadap Tingkat Kemiskinan di Kalimantan Barat, Jurnal Ekonomi, Bisnis dan Kewirausahaan, 2(2), 55-76.

Yunan. (2009). Analisis Faktor-Faktor yang Mempengaruhi Pertumbuhan Ekonomi Indonesia. (Tesis yang tidak dipublikasikan), Universitas Sumatera Utara, Indonesia.

Zulyanto, A. (2010). Pengaruh Desentralisasi Fiskal terhadap Pertumbuhan Ekonomi di Provinsi Bengkulu. (Tesis yang tidak dipublikasikan), Universitas Diponegoro, Indonesia. 